\title{
Ethics and Regulation of Clinical Research
}

Second Edition 
Entia non sunt multiplicanda praeter necessitatem William of Occam 


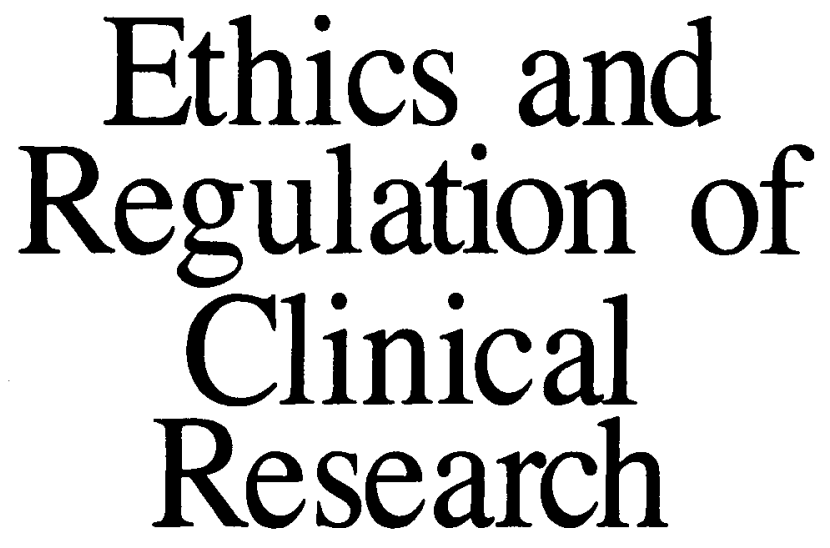

Robert J. Levine

Professor of Medicine

Yale University, School of Medicine

New Haven, Connecticut

Second Edition

Yale University Press

New Haven and London 
First published 1986 by Urban \& Schwarzenberg. Published 1988 by Yale University Press.

Copyright ${ }^{\circ} 1986$ by Urban \& Schwarzenberg.

All rights reserved.

This book may not be reproduced, in whole or in part, including illustrations, in

any form (beyond that copying permitted by Sections 107 and 108 of the U.S. Copyright Law and except by reviewers for the public press), without written permission from the publishers.

Printed in the United States of America

Library of Congress cataloging card number: $87-51614$ International standard book number: 978-0-300-04288-7

The paper in this book meets the guidelines for permanence and durability of the Committee on Production Guidelines for Book Longevity of the Council on Library Resources. 
To the Memory of

Henry K. Beecher and Franz J. Ingelfinger

and for

John, Elizabeth, and Jeralea,

My touchstones to validity 
This page intentionally left blank 